\title{
The Effort of Equalling the Distribution of Education Facility in Cooperation with Houses of Worship
}

\author{
Nurmala Berutu ${ }^{1}$, Restu, Mbina Pinem, Nina Novira, Jian Maxriz \\ \{nurmala_geo@yahoo.co.id ${ }^{1}$, erestege@yahoo.com,mbinapinem@yahoo.com\} \\ Geography Education Department, Universitas Negeri Medan. Jalan Willem Iskandar, Indonesia
}

\begin{abstract}
One of the main obstacles in the distribution of education in Indonesia is the provision of school building infrastructure that certainly requires a high cost both in terms of raw materials plus accessibility to mobilize raw materials for the construction of school buildings. On the other hand, houses of worship can be found very easily up to remote villages. This study aims to determine the response of the community, community leaders, and responses from government agencies related to the concept of equal distribution of education facilities in cooperation with houses of worship. Based on BPS data elementary schools are not found in every village, whereas in most of the villages there are one or more houses of worship. The method used in this study is direct observation, in-depth interviews with key informants (Village Heads and Religious Leaders), and expert interviews with government service agencies (Education Offices and Religious Departments) in the study area. The approach used in this study is a qualitative approach with Prospect Theory as the conceptual framework. The overall results showed that basically, the people have no objection TOT the concept. However, there are obstacles and potential in implementing the concept.
\end{abstract}

Keywords: Equal distribution of education, cooperation, house of worship.

\section{Introduction}

Education is a very fundamental thing and plays an important role in the development of human resources, and as a way to advance a nation because a strong nation is a nation that has superior and quality human resources, and excels in the field of education as a step to educate life nation. Education is the right of every citizen, as mandated in Law number 20 of 2003 that every citizen has the same right to obtain a quality education. But this seems to be inversely proportional to reality [1].

Indonesia's pure enrollment rate at the elementary level is indeed already quite high at 97.19. However, often in remote areas, children have to travel great distances to reach school. On the other hand, it was recorded that up to 4 September 2018 there were still 3.4 million or around $2.07 \%$ of occupants in Indonesia who were still illiterate. Of course, this shows that the gap in education in Indonesia is still quite high [2].

The education gap is also very contrastable when comparing school buildings in cities and school buildings in rural areas, of course, there are very clear gaps both in terms of facilities and of course, it is a bitter reality. When the Indonesian people were incessantly talking about the industrial revolution 4.0, there were still many children of the nation who could not yet enjoy proper and quality education as they should. In some villages located in the interior of Indonesia, the young generation of Indonesia only goes to school which has a roof that has a 
leak and has a dirt floor. Schools in the village are generally only at the elementary school level. There are still many villages that do not have a school at all. The government certainly has carried out a variety of policies to address the issue of equitable education, but often the obstacles faced by the government are the construction of school infrastructure which requires enormous costs and access to villages that are in the interior which is quite difficult.

On the other hand, the existence of places of worship is almost always in every village, both villages that are easily accessible and villages that are in the interior. Based on this, it can be promoted even distribution of education based on houses of worship, namely the implementation of education carried out in houses of worship whether mosques, churches or other religious places of worship. The mosque as a place of worship of Muslims is not used all day. For praying itself only 5 times, early morning, at noon, afternoon, evening, and night, so that from morning until noon the mosque is not used to perform compulsory worship. This time is very possible to carry out the teaching and learning process.

Besides being used as a place of worship, the mosque is also the center of the life of the Muslim community. Activities such as celebrating holidays, discussions, religious studies, lectures and learning the Qur'an are often carried out at the mosque. Even in the history of Islam, mosques also play a role in social community activities, so that this religious housebased education program is very relevant to be implemented in mosques. So it is with houses of worship of Christians. Christians do worship only on Sundays so that from Monday to Saturday the teaching and learning process can be done in the house of worship. Likewise, the houses of worship of Buddhists and Hindus are not used all day long for worship.

The education gap will certainly have an impact on the Human Development Index in North Sumatra. According to BPS data, the Human Development Index in North Sumatra in 2017 is still at 70.57, lower than the West Sumatra Province whose Human Development Index is at 71.24. By organizing education in places of worship, of course also will encourage students to be more active in worship and of course, it is expected that environmental factors can affect the morale of students because of the place of learning carried out in places of worship. As well as going to train more transparency between students because in the implementation of learning it could be that Muslim students take part in learning in the church and vice versa.

By utilizing a house of worship as a location for conducting education, the government no longer needs to think about the physical facilities of the school and only think about providing educators/teachers who will conduct the teaching and learning process at schools located in places of worship. The Education Program must be more vigorous to be carried out considering that in 2045 Indonesia will be 100 years old, and at that time Indonesia will enter a golden age because of getting a demographic bonus, where the productive age will be more than the unproductive age. Of course, to get a golden age, Indonesia must have qualified and qualified Human Resources (HR). This can only be obtained through quality and equitable education. Houses of worship are important religious facilities for followers of a religion in a place. Aside from being a symbol of the "existence" of religious adherents, a place of worship is also a place for broadcasting religion and a place of worship. This means that the function of the house of worship besides as a place of worship is expected to provide a strong and directed impetus for the congregants so that the religious-spiritual life for followers of the religion will be better and one of the places of worship in question is the mosque [3]. 


\section{Methods}

\subsection{Case study location}

This research will be carried out in Naga Juang, Mandailing Natal Regency, which is a result of the division of Siabu District so that the District is still quite young. The sub-district was chosen as a research area because in that place several villages did not have an elementary school, but had a sufficient number of houses of worship ranging from churches, mosques, and langar, so it was possible to implement an equal distribution program for places of worship.

Based on BPS data (see Table 1), the number of elementary schools in Naga Juang Subdistrict, which includes 7 villages, only has 5 elementary schools, there are still 3 villages without primary schools with 909 school-aged people, reaching 909 people, with a number of houses of worship 16 (Mosque, Mosque, Protestant Church, Catholic Church). Surely the situation will be very supportive of the implementation of the concept in this area [4].

Table 1. Number of Villages, Schools, School-aged Inhabitants, and Houses of Worship in Naga Juang Sub-District.v

\begin{tabular}{ccccccc}
\hline No & Sub-District & Villages & Schools & School-aged Inhabitants & $\begin{array}{c}\text { Houses of } \\
\text { Worship }\end{array}$ \\
\hline & & & & $5-9$ & $10-14$ & \\
\multirow{2}{*}{1} & Naga Juang & 7 & 5 & 467 & 442 & 16 \\
& TOTAL & 7 & 5 & 909 & 16 & \\
\hline
\end{tabular}

\subsection{Conceptual framework}

To understand the level of community acceptance concerning potential benefits and risks, we use Prospect Theory. Prospect Theory explains that when faced with choices that have potential risks, a person tends to prefer the possibility of getting bigger things than getting something that is certain but smaller. There is the risk that will be perceived by the community, namely related to the benefits of having a school that is closer to where you live if you accept the concept of organizing formal education in places of worship as a substitute for school buildings.

\subsection{Data collection method}

The methods used to obtain data in this study were in-depth interviews with key informants (Village Heads, villagers and Religious Leaders), expert interviews with government service agencies (the Department of Education and the Regional Religion Office) in the study area, and focus group discussion (FGD) ) to people who will be differentiated according to age group. The approach used in this study is qualitative.

\subsection{Data analysis method}

The collected data will be analyzed using the Daily Interpretive Analysis method, which will conduct a preliminary analysis of the results of the interviews and FGD every day and also formulate initial conclusions. The results of the preliminary analysis and initial conclusions will be analyzed again after all interviews and FGDs have been completed. 


\section{Result and discussion}

Based on the results of interviews conducted with religious leaders in Naga Juang District, it is true that in addition to a place of worship both a mosque or a church is also a place of education and the distribution of education based on houses of worship is very appropriate to be applied in villages / regions that do not have school or takes a long time to go to the nearest school, especially in areas that are still remote where the terrain to the nearest school is still relatively extreme where it must pass through the forest or across the river.

But by making the house of worship a place for formal education, it means that all students will be able to enter the house of worship, where Muslims will be able to enter the church and non-Muslims will also be able to enter the mosque. The majority of Islamic religious leaders who serve as informants provide information about disagreement if nonMuslims enter the mosque even though it is for educational purposes, because according to the religious leaders that the mosque is a holy place and should not be entered by just anyone especially those who are not Muslim. There is even culture in one of the villages used as a research location where the culture prohibits local people from smoking in the mosque. In addition, the main factor of disagreement among Islamic religious leaders about this is the matter of cleanliness, but not physical cleanliness but spiritual cleanliness, there is a kind of stigma in society that non-Muslims cannot enter the mosque because their souls are impure and there is also no presence Purgatory in other religions further reinforces the stigma.

However, if under certain conditions and conditions, such as the road to the nearest school is very far, and dangerous such as having to pass through the forest, crossing the river, nonMuslim students are allowed to attend education in the mosque with the local community agreement. Meanwhile, for the views of Christian religious leaders, they allow if the church is used as a place for organizing formal education and non-Christians take part in it because in the context of education. Meanwhile, if the implementation of formal education is carried out in the church, Islamic religious leaders in Naga Juang district provide a view that allows if Muslim students attend formal education in the church as long as the context is education and not the discussion of other religions that are not embraced by the students. Likewise, the religious leaders of Nasrani do not mind if Christian students attend formal education in the mosque, provided the notes taught are knowledge in formal schools, not discussing Islamic religion and not influencing non-Muslim students to convert to Islam.

Education is very important, and people in Naga Juang sub-district are aware of the urgency of education itself. But it is almost the same as the views of religious leaders, because basically what affects the views of people in the village is religious leaders, traditional leaders, or leaders in the village, so it is not surprising that the opinions of religious leaders are often in line with the views of the community. As the main characteristic of the village is the customs and culture that is still very thick.

Similar to the views of religious leaders, that the people in Naga Juang District agreed that the House of Worship was not only a place of worship but could also be used as a place of education, both formal and informal. But the people who are Muslim do not agree if the mosque is made as a place for organizing education and non-Muslim people enter the mosque, for reasons that are almost the same as religious leaders, namely related to personal purity. The view that non-Muslims are impure is not allowed into the mosque to be the main cause.

This is different from the view of the Humbang 1 village community, where the village community is $100 \%$ Christian and believes that those who are not Christian are allowed to enter the church, especially for educational purposes. Even the people in this village feel that if education were held at the mosque, the people who were Muslim would not accept them to 
enter the mosque. To carry out formal education in the church, the entire community in Naga Juang Subdistrict gave an allied opinion, be it a Muslim or a Christian community, with the notes discussed were knowledge like informal schools in general, not discussing a particular religion. However, there are several different communities of view, namely the young people, where young people in Naga Juang Subdistrict are more open, one of Padang State University students who come from Tambiski Village, Naga Juang Subdistrict as interview respondents, giving an opinion that it is not a matter of special houses of worship. the mosque was made as a place for organizing education both for those who are Muslim and those who are not Muslim because for educational purposes, a good goal.

Naga Juang Subdistrict is a subdistrict that is divided into 7 villages, out of 4 village heads who are used as interview respondents, 3 village heads where the population is entirely Muslim are strict if the mosque is not only a place of worship but also has other functions such as a place of education. But the same is true of the views given by Islamic religious leaders, namely disagreeing if non-Muslims are not allowed to enter the mosque for almost the same reasons related to holiness. While the village head of Humbang 1 expressed a different view, he said that it was not a problem if the house of worship, either the mosque or the church, was used as a venue for both Islamic and Christian education. He even explained that if there were two schools in a village, a public school, and a Muhammadiyah school, he would prefer a school to Muhammadiyah so that he could increase his knowledge and insight.

In the village of Humbang itself, at first the school had opened a school of basic knowledge education including reading and writing, then because the program was considered good, the village adjacent to the village of Humbang 1 made an agreement between villages, namely related to the construction of educational sites, then the government responded well to the plan so that the government provide subsidies to stand up Aek Nauli Elementary School.

From the government agency itself, especially the education office gave an opinion based on the results of an interview conducted on one of the heads of education in Mandailing Natal district, he said that the concept of equal distribution of education was very good as an effort to equalize education, but the education office-oriented more towards the agreement of the people who were in a village where the concept of equal distribution of education based on houses of worship will be applied, if the community accepts it then the education office will provide both material and non-material assistance. But the Mandailing Natal district education office said it would try to ensure that the concept was not necessary to be applied. The government will certainly strive to build adequate school infrastructure. The education office also confirmed that the house of worship is a place that has a variety of functions in addition to its main function, namely as a place of worship also is a place of education.

\section{Conclusion}

There is religious polarization in Naga Juang Sub-District, with 5 Islamic villages and 2 Christian villages. The majority of people in Islamic villages accept the idea of using the mosque as a substitute for a school building but do not agree if children of other faiths attend school at the mosque. On the other hand, they can accept if a Muslim child goes to school in a church building as long as there is no content to invite other religions. The majority of people in Christian villages do not object to all ideas of implementing education based on houses of worship. Personally, the Head of the Mandailing Natal District Education Division did not 
object to the idea of implementing a house of worship-based education. But institutionally, it is difficult to be realized.

\section{References}

[1] Winataputra, Udin Saripudin, et al. "Teori belajar dan pembelajaran." (2014): 1-46.

[2] Pane, Aprida, dan Muhammad Darwis Dasopang. "Belajar dan pembelajaran." Fitrah: Jurnal Kajian Ilmu-ilmu Keislaman 3.2 (2017): 333-352.

[3] Putri, Nella Sumika. "Pelaksanaan Kebebasan Beragama di Indonesia (External Freedom) Dihubungkan Ijin Pembangunan Rumah Ibadah." Jurnal Dinamika Hukum 11.2 (2011): 230-242

[4] Badan Pusat Statistik: Kecamatan Naga Juang Dalam Angka. BPS Kabupaten Mandailing Natal, Panyabungan (2017). 